\title{
Identifikasi Penerapan ERP dan Resiko Managemen Pada RSUD Dr Samratulangi Tondano Kabupaten Minahasa Sulawesi Utara
}

\author{
Frendy Rocky Rumambi*, Citra Amalia, Rully Alexander \\ Magister Teknik Informatika, Universitas Atma Jaya Yogyakarta \\ Naskah Diterima : 8 Agustus 2018; Diterima Publikasi : 21 September 2018 \\ DOI : 10.21456/vol8iss2pp149-156
}

\begin{abstract}
Influential information technology in all areas of one field of health evidenced denganteknologi can help health services in the form of examination, diagnosis, treatment, and decision making. The role of information technology in the sphere of kesehatandapat providing services and address the risks. The purpose of this research is to study how the application of ERP and risk management at hospital. It was concluded that an ERP system successfully applied in the field of health there are risks regarding the service. ERP systems can improve health services. The lack of research in this field, furthermore investigates the use of ERP in the field of health and the application of risk management. conclusion, used system ERP at the hospital has not been applied as a whole, many clinical functions as well as a database on the health section at the hospital have not yet integrated, sistemhanya focuses on the function of registration and administration comparison of clinical function, there are many risks facing health care providers especially about service. Factor in the availability of technology and human resources to the implementation of the ERP system and risk management.
\end{abstract}

Keywords : Information Technology; Hospital; ERP; Risk Management; Business Process; Integration.

\section{Abstrak}

Teknologi informasi berpengaruh besar di semua bidang salah satunya bidang kesehatan yang dibuktikan denganteknologi dapat membantu pelayanan kesehatan berupa pemeriksaan, diagnosis, perawatan, dan pengambilan keputusan. Peran teknologi informasi di bidang kesehatandapat memberikan pelayanan yang maksimal dan mengatasi resiko. Tujuan penelitian ini adalah untuk mengetahui bagaimana penerapan ERPdan managemen resikopada rumah sakit. Disimpulkan bahwa sistem ERP berhasil diterapkan dibidang kesehatan namun terdapat resiko menyangkut pelayanan.Sistem ERP dapat meningkatkan pelayanan kesehatan. Kurangnya penelitian dibidang ini, diharapkandapat menyelidiki penggunaan ERP di bidang kesehatan dan penerapan managemen resiko.Kesimpulanya,penggunaansistem ERP pada rumah sakit belum di terapkan secara keseluruhan, banyak fungsi klinis maupun database pada bagian kesehatan pada rumah sakit belum terintegrasi, sistemhanya berfokus pada fungsi registrasi dan administrasi dibandingkan fungsi klinis, banyak terdapat resiko yang dihadapi penyedia layanan kesehatan terutama mengenaipelayanan. Faktor ketersediaan teknologi dan SDM berpengaruh terhadap penerapansistem ERP dan managemen resiko.

Kata kunci : Teknologi Informasi; Rumah Sakit; ERP; Managemen Resiko; Proses Bisnis; Integrasi.

\section{Pendahuluan}

Teknologi informasi telah merambah kesektor kesehatan. Hal itu terbukti bahwa teknologi dapat memberikan dampak yang positive terhadap pelayanan kesehatan kepada masyarakat berupa pemeriksaan, diagnosis, perawatan, menindaklanjuti dan sampai pada pengambilan keputusan medis (Debiao et al., 2011). Pengaruh teknologi informasi bersumber dari pengetahuan, pengalaman, keterampilan, status komputerisasi, sikap professional serta keyakinan positif atau negatif *) Penulis korespondensi: frensrumambi@yahoo.com mereka tentang sistem yang berjalan dalam sebuah Rumah Sakit (Zhu, 2012).

Dari hasil survei yang dilakukan dapat dilihat bahwa RSUD Dr Samratulangi Tondano Kabupaten Minahasa Sulawesi Utara belum menerapkan sistem ERP secara keseluruhan. Pihak RS mengunakan sistem billing berupa SIRS untuk menangani semua proses yang terjadi, mulai dari proses registrasi pasien, pemeriksaan kesehatan dan sampai pada proses managemen (Poba-Nzaou et al., 2012).

Sistem yang digunakan saat ini belum terintegrasi secara keseluruhan, sistem yang berjalan hanya 
terdapat pada dua bidang saja yaitu bagian registrasi data pasien dan bagian administrasi. Demi meningkatkan kualitas dan kinerja karyawan dalam RS, maka sebuah instansi kesehatan terlebih khusus rumah sakit harus memiliki sebuah sistem yang terpadu (Hemsley et al., 2012), (UUD No 46 pasal 1, 2014).

Dalam proses pelayanannya pengguna sistem banyak mengalami kendala ketika mengoprasikannya (Oluwatosin, 2014). Masalah yang sering di jumpai adalah informasi data pasien terkadang tidak akurat, berbagai fungsi SIRS tidak berjalan sebagaimana mestinya dan pengguna lebih memilih menggunakan cara manual ketika mengalami kendala atau error. Berdasarkan beberapa masalah tersebut, peneliti mengambil kasus ini untuk mengidentifikasi penerapan ERP dan resiko managemen pada rumah sakit daerah (Karan et al., 2012).

Informasi dan integrasi merupakan aspek penting bagi industry kesehatan. Penggunaan TI telah didorong oleh keinginan untuk mengurangi biaya, meningkatkan daya saing dan meningkatkan layanan kesehatan. Maka dari itu TI menjadi salah satu sumber daya utama dan menjadi salah satu poin terpenting dalam pelayanan kesehatan di rumah sakit (Chen, 2016).

Melihat pentinganya ERP dan managemen risiko di bidang kesehatan, maka penelitian ini dilakukan untuk mencari cara demi memperbaiki layanan kesehatan dengan menerapkan sistem ERP dan managemen resiko (Agarwal et al., 2012).

Secara umum, lingkungan bisnis saat ini telah mengambil bentuk yang berbeda.Sistem ERP sangat penting dalam meningkatkan efisiensi organisasi dan pengambilan keputusan strategisnya (Lee and Kwak, 2011). Namun, dalam menerapkan ERP di lingkungan kesehatan akan menghadapi beberapa tantangan seperti jangka waktu yang lama dan resiko yang harus di hadapi dalam melakukan implementasi sistem (Nowak, 2014).

Penelitian ini berfokus pada bagaimana sistem ERP dan managemen resiko di terapkan dan digunakan dalam organisasi kesehatan untuk meningkatkan efisiensi kinerja mereka. Organisasi kesehatan tradisional menggunakan sistem informasi terpisah (Kerezoglou, 2011). Oleh karena itu, organisasi ini ditantang untuk berbagi informasi penting di antara entitas yang berbeda (Gheorghiu, 2016). Studi ini juga menyoroti manfaat ERP dan managemen resiko bagi organisasi kesehatan seperti RS.

Manfaat yang peneliti peroleh dari penelitian ini adalah dapat mengetahui mengenai faktor-faktor apasaja yang mempengaruhi penerapan sistem ERP dan managemen resiko, memberikan saran serta solusi dalam penerapan managemen resiko dan pengembangan ERP kedepan nanti (Huq et al., 2012), ( Maditinos et al., 2012).

\section{Kerangka Teori}

\subsection{Teknologi Informasi}

Teknologi Informasi (TI) adalah suatu studi perancangan, penerapan, pengembangan, dukungan atau manajemen sistem informasi berbasis teknologi komputer, yang berkaitan dengan hardware dan software (Sutarman, 2009), (Al-Zaidiyeen et al., 2018). TI mencangkup fasilitas yang dapat mendukung dan meningkatkan pekerjaan manusia dalam bidang informasi sehingga menghasilkan sesuatu yang berkualitas (Edy, 2014).

\subsection{Rumah Sakit}

Rumah Sakit (RS) adalah suatu instansi yang memberikan pelayanan kesehatan yang prima kepadamasyarakat. Konstitusi Indonesia No. 44 pasal 52 ayat 1 Tahun 2009 mengenai proses kerja rumah sakit (Depkes, 2009), (Kepmenkes RI, 2007). Penilaian RS berdasarkan dari pelayanan yang diberikan kepada masyarakat yaitu dari kinerja para dokter, perawat, bagian pendaftaran atau administasi, staf rumah sakit, apoteker serta seluruh kinerja pada managemen rumah sakit. (Alexandra, 2012).

\subsection{Integrasi System Informasi Rumah Sakit}

Integrasi Sistem Informasi pada RS adalah sistem komputerisasi yang menjadi satu kesatuan dan terkordinasi untuk proses bisnis berupa pelaporan dan prosedur administrasi demi untuk mendukung kinerja dan memperoleh informasi secara real time (El-Kareh et al., 2013), tepat dan akurat. Sistem Informasi Manajemen (SIM) berbasis computer merupakan sistem support atau bahkan primary untuk proses manajemen rumah sakit (Hriningsih, 2015).

\subsection{Enterprise Resource Planning (ERP)}

ERP digunakan untuk institusi besar, salah satunya RS. ERP merupakan sistem informasi atau perancangan software untuk perusahaan manufaktur dan jasa yang dapat mengintegrasikan dan memberikan enable pada proses bisnis yang berhubungan dengan bidang produksi maupun distribusi pada perusahaan (Azhari, 2015), (Barlin, 2016).

\subsection{Enterprise Resource Planning(ERP) Di Bidang} Kesehatan

Organisasi kesehatan menangani sejumlah besar informasi yang adamisalnya, RS menangani data dari berbagai departemen, beberapa di antaranya harus dibagi agar bisa memberikan layanan. Informasi tersebut digunakan secara berbeda sesuai fungsi departemen, seperti pengendalian dan perencanaan. (Garg, 2014).

Informasi merupakan bagian penting dari sistem kesehatan, maka sistem ini dapat memudahan tugas dokter, perawat, pasien, dan tugas perawatan pasien. Sistem terpadu akan memungkinkan organisasi 
kesehatan mengkoordinasikan manajemen dan mendukung efisiensi perawatan pasien (Handayani, 2013).

Menurut penelitian yang ada beberapa ahli berpendapat bahwa banyak lingkungan bisnis telah berubah, termasuk juga sektor kesehatan. (Snyder, 2016). ERP dapat membantu sektor kesehatan dengan meningkatkan integrasi proses dan layanan, konsep dasar ERP ditunjukkan pada Gambar 1.

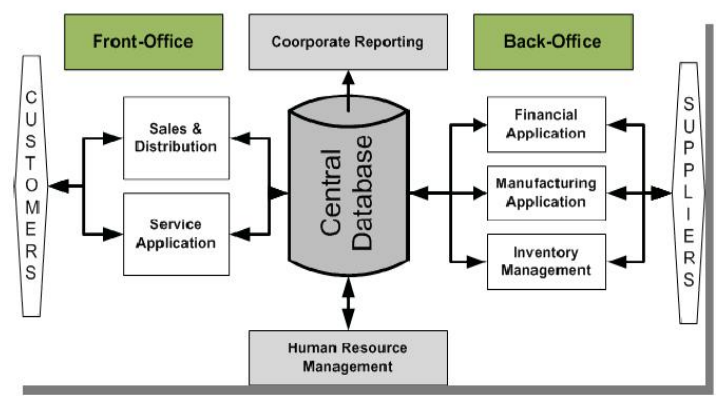

Gambar 1. Konsep dasar ERP secara umum

\subsection{Managemen Resiko Rumah Sakit}

Manajemen risiko RS adalah suatu kegiatan analisis resiko dan evaluasi untuk mengurangi dan menghilangkan dampak risiko yang ada. Keputusan untuk menyelesaikan resiko yang terdeteksi untuk mencapai keseimbangan optimal antara risiko, keuntungan dan biaya, untuk konsep managemen resiko dapat dilihat pada Gambar 2.

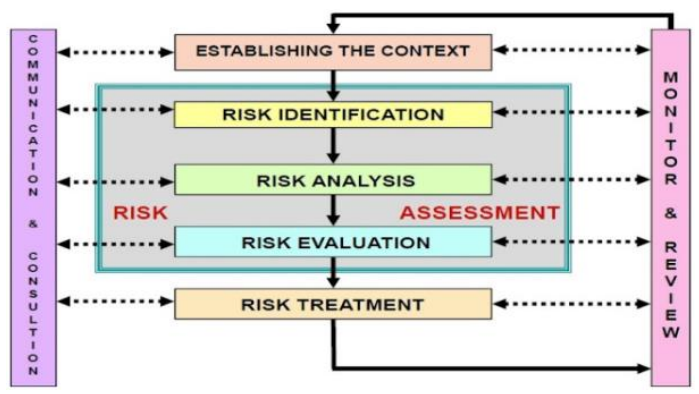

Gambar 2. Konsep managemen resiko

\subsection{Manajemen Risiko Rumah Sakit}

Managemen Risiko RS menyangkut keselamatan pasien meliputi risiko pasien, analisis, identifikasi dan pengelolaan (Padhy, 2012). Managemen risiko RS harus di terapkan demi meminimalkan, menghilangkan dan mencegah terjadinya dampak yang akan terjadi (Mawarni, 2013), (Iskandar et al., 2014).

Pengaruh risiko dapat berdampak terhadap kondisi:Sumber Daya (human and capital), produk dan jasa dan pelanggan. Dampak eksternal bisa terhadap masyarakat, pasar atau lingkungan, rantai pasok, manajemen perusahaan, production, dan pemasaran.

Kategori risiko yang terdapat pada $\mathrm{RS}$ (Categoriesof Risk) adalah sebagai berikut:Patient care care-related risks, Medical staff staff-related risks, Employee Employee-related risks, Property Property-related risks, Financial risks dan Other risks.

\subsection{Identifikasi Resiko}

Identifikasi akan membantu untuk mengambil langkah-langkah yang akan diterapkan pihak manajemen RS terhadap risiko tersebut.

Pendekatan terhadap identifikasi risiko meliputi:

a. Brainstorming atau bertukar pikiran

b. Mapping out proses dan prosedur di rumah sakit dan menanyakan kepada pegawai tentang identifikasi risiko pada setiap bagian.

c. Membuat rincian risiko dan menanyakan kembali sebagai umpan balik.

Penilaian risiko (Risk Assesment) merupakan proses untuk membantu pihak manajemen dalam melakukan penilaian tentang risiko yang akan dihadapi.RS harus memiliki standar program Risk Assessment tahunan, yakni Risk Register sebagai berikut:

a. Risiko yang teridentifikasi dalam kurun waktu 1 tahun.

b. Informasi insiden pasien, klaim litigasi dan komplain, investigasi eksternal dan internal, external assessments dan akreditasi.

c. Informasi potensial risiko maupun risiko actual (menggunakan RCA\&FMEA).

\subsection{Manfaat Managemen Resiko Terintegrasi}

Manfaat manajemen risiko terintegrasi dalam ERP untuk rumah sakit adalah sebagai berikut:

a. Informasi lebih rinci

b. Mempelajari salah satu area risiko sehingga dapat diterapkan pada area risiko lainnya.

c. Pendekatan dilakukan secara konsisten untuk identifikasi, analisis dan investigasi pada semua risiko, yaitu menggunakan Root Cause Analysis (RCA).

d. Membantu manajemen RS dalam standar-standar yang diterapkan, serta kebutuhan tata kelola klinis.

e. Memberikan perencanaan pada RS untuk menghadapi ketidakpastian, penanganan dampak dari kejadian yang tidak diharapkan, dan meningkatkan kepercayaan masyarakat terhadap rumah sakit.

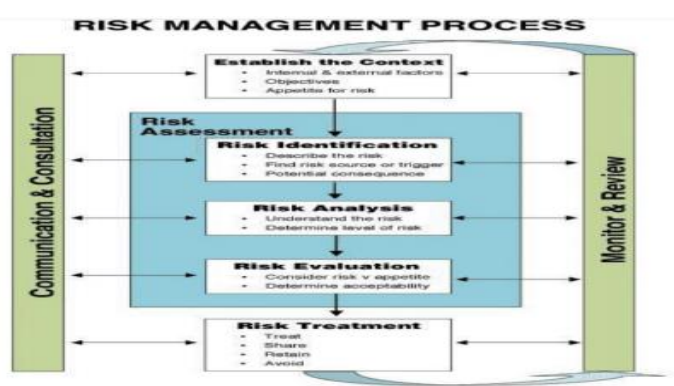

Gambar 3. Risk Managemen Process,( ISO 31000, 2009) 
Alat untuk melakukan penilaian resiko yang digunakan dalam menangani risiko yang terjadi adalah Risk Matrix Gradin, Root Cause Analysis dan Failure Mode and Effect Analysis

\section{Metode}

Penelitian ini dilakukan untuk identifikasi bagaimana sistem ERP dan managemen risiko di terapkan sehingga dapat berpengaruh dan berdampak baik terhadap pihak RS dan pasien serta masyarakat. Tahapan penelitian yang dilakukan peneliti menjelaskan tentang langkah-langkah yang dilakukan pada peneliti ini. Pengambilan data dilakukan dengan 2 tahapan yaitu obeservasi dan wawancara pada RSUD Dr. Samratulangi Tondano. Tahapan penelitian dapat dilihat dari Gambar 4.

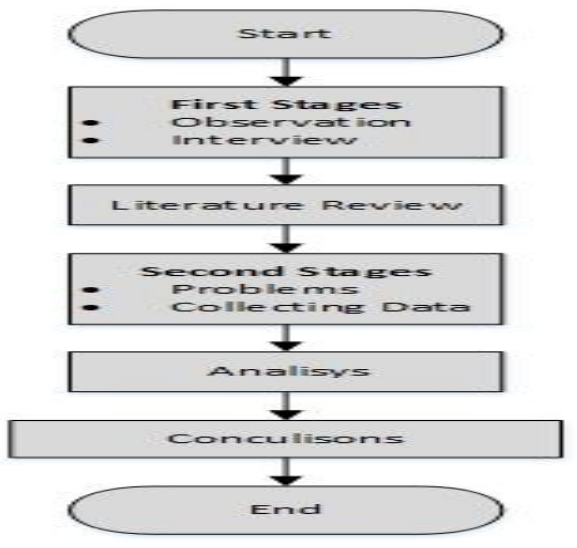

Gambar 4. Langkah-langkah penelitian

Dalam studi ini dilakukan obeservasi, tinjauan pustaka, menganalisa masalah yang ada dan melakukan analisa.Tinjauan literatur juga dapat menjelaskan dan Dalam studi ini, pustaka yang digunakan antara lain ialah Google Scholar, IEEE, Ilmu Pengetahuan Langsung, Web of Science.

\section{Hasil dan Pembahasan}

\subsection{Hasil Penelitian}

Penerapan sistem ERP dan managemen risiko pada bidang kesehatan dapat membawa sebuah perubahan yang cepat, memimpin organisasi yang relevan dan dapat merespons kebutuhan pasar saat ini. Namun di dalam penerapan sistem ERP dana managemen risiko pihak RSakan menghadapiberbagai masalah yang serius, terutama disebabkan oleh banyaknya informasi yang dihasilkan setiap hari, meningkatnya biaya persediaan, kegagalan sensus pasien, pembayaran medis, kurangnya staf khusus dan lain sebagianya.

Dalam penerapan sistem ERP maka di perlukan sebuah integrasi database yang secara umum bertujuan untuk menghubungan masing-masing database yang terdapat pada satu atau lebih bidang kesehatan yang ada dalam sebuah rumah sakit.
Integrasi database juga harus mempunyai sebuah struktur yang kompleks dan efesien.

Berbagai macam masalah teridentifikasi dalam proses penerapan. Masalah tersebut dikelompokkan kedalam tujuh domain yaitu data, teknologi, proses bisnis, kognisi personel, kapabilitas personel, manajemen dan lingkungan, hal ini dapat dilihat pada Tabel 1.

Tabel 1. Hasil temuan

\begin{tabular}{|c|c|c|c|}
\hline No & Domain & Masalah & Keterangan \\
\hline \multirow[t]{2}{*}{1} & Data & Ketersediaan & 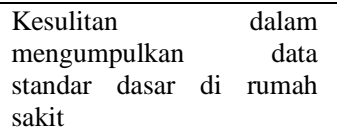 \\
\hline & & format & $\begin{array}{l}\text { Data dasar masih data } \\
\text { hardcopy }\end{array}$ \\
\hline \multirow[t]{3}{*}{2} & Teknologi & Ketersediaan & $\begin{array}{l}\text { Komputer tidak tersedia } \\
\text { disemua divisi rumah sakit }\end{array}$ \\
\hline & & Kualitas & $\begin{array}{l}\text { Jaringan internet kurang } \\
\text { memadai }\end{array}$ \\
\hline & & Kesesuaian & $\begin{array}{l}\text { Teknologi yang ada tidak } \\
\text { sesuai dengan sistem }\end{array}$ \\
\hline \multirow[t]{3}{*}{3} & Proses & Penyesuaian & Masalah \\
\hline & Bisnis & & $\begin{array}{l}\text { menyesuaikan proses } \\
\text { bisnis dan sistem yang } \\
\text { dijalankan rumah sakit }\end{array}$ \\
\hline & & $\begin{array}{l}\text { Pendamping } \\
\text { an }\end{array}$ & $\begin{array}{l}\text { SDM yang kurang } \\
\text { memadai } \\
\text { pendamping implementasi } \\
\text { dan penerapan sistem }\end{array}$ \\
\hline \multirow[t]{2}{*}{4} & $\begin{array}{l}\text { Kognisi } \\
\text { personel }\end{array}$ & Respon & $\begin{array}{l}\text { SDM kurang bersemangat } \\
\text { dalam merespons } \\
\text { kehadiran sistem baru yang } \\
\text { di gunakan }\end{array}$ \\
\hline & & Konsistensi & $\begin{array}{l}\text { SDM kurang aktif dalam } \\
\text { menjalankan system }\end{array}$ \\
\hline \multirow[t]{2}{*}{5} & $\begin{array}{l}\text { Kapabilitas } \\
\text { personel }\end{array}$ & Kemampuan & $\begin{array}{l}\text { Keterampilan SDM dalam } \\
\text { menggunakan system } \\
\text { informasi sangat kurang }\end{array}$ \\
\hline & & Pelatihan & $\begin{array}{l}\text { Tidak adanya pelatihan dan } \\
\text { sertifikasi dalam } \\
\text { penggunaan sistem }\end{array}$ \\
\hline \multirow[t]{8}{*}{6} & Manajemen & Sosisalisasi & Manajemenrumah sakit \\
\hline & & & $\begin{array}{lr}\text { tidak } & \text { memberikan } \\
\text { sosialisasi penggunakan } & \text { pengat } \\
\text { sistem secara tepat }\end{array}$ \\
\hline & & Delegasi & $\begin{array}{lr}\text { Kesulitan } & \text { dalam } \\
\text { mendelegasikan } & \text { pekerjaan }\end{array}$ \\
\hline & & & $\begin{array}{lll}\text { kepada } & \text { SDM } & \text { yang } \\
\text { ditunjuk } & & \end{array}$ \\
\hline & & Mobilisasi & $\begin{array}{lr}\text { Manajemen } & \text { tidak } \\
\text { mendukungSDM } & \text { untuk } \\
\text { menggunakan } & \\
\text { Sistem yang ada } & \end{array}$ \\
\hline & & Evaluasi & $\begin{array}{lrr}\text { Tidak } & \text { ada evaluasi } \\
\text { terhadap } & \text { pengoperasian } \\
\text { sistem } & & \end{array}$ \\
\hline & & Konsistensi & $\begin{array}{l}\text { Tidak adanya keputusan } \\
\text { yang diterapkan untuk } \\
\text { menunjang pelayanan }\end{array}$ \\
\hline & & Penghargaan & $\begin{array}{ll}\text { Tidak ada skema } \\
\text { penghargaan } & \text { dalam } \\
\text { penggunakan sistem } & \end{array}$ \\
\hline \multirow[t]{2}{*}{7} & Lingkungan & Utilitas & $\begin{array}{l}\text { Utilitas listrik kurang } \\
\text { memadai }\end{array}$ \\
\hline & & $\begin{array}{l}\text { Jarak } \\
\text { Geografis }\end{array}$ & $\begin{array}{l}\text { Jarak rumah sakit kurang } \\
\text { strategis }\end{array}$ \\
\hline
\end{tabular}




\subsection{Integrasi Database}

Dengan adanya integrasi database di RS maka semua data pasien dapat dengan mudah ditemukan dan tidak perlu menambahkan data baru. Sistem yang sering digunakan pihak RSUD Dr Samratulangi Tondano, dapat dilihat pada Gambar 5.

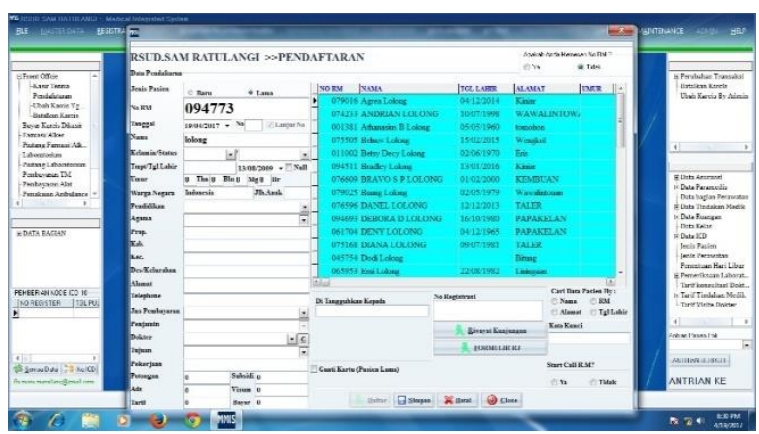

Gambar 5. Tampilan menu sistem registrasi rumah sakit

\subsection{Proses Bisnis}

Proses bisnis adalah kumpulan aktivitas kegiatan yang terstruktur dan saling terkait demi menghasilkan produk atau output tertentu (Purnawati, 2018). Proses bisnis terdiri dari beberapa subproses dan memberikan berkontribusi untuk mencapai tujuan dari setiapsub prosesnya. Berikut ini adalah beberapa karakteristik umum dalam proses bisnis

a. Definitif merupakan sebuah proses bisnis yang tidak dapat diubah karena ini merupakan data final yang memiliki batasan, inputan, serta output yang jelas.

b. Urutan adalah proses bisnis yang terurut secara tepat sesuai dengan tahapan yang ditetapkan.

c. Pelanggan adalah subjek dalam sebuah proses bisnis yang memiliki keluaran dan dapat diproses.

d. Nilai tambah adalah transformasi yang terjadi dalam proses bisnis memberikan nilai lebih pada dapat menerima.

e. Keterkaitan adalah suatu hal yang memiliki keterikatan antara satu dan lain dan kesatuan yang utuh.

f. Fungsi silang adalah proses fungsi yang diterapkan secra silang pada subjek atau objek dan proses lain.

Selanjutnya adalah salah satu proses bisnis yang sering terjadi di RSUD Dr Samratulangi Tondano, dapat dilihat pada Gambar 6 dan Gambar 7.

Proses bisnis secara umum menjadi sembilan layer utama yaitu operational layer,service component layer, service layer, bussines proses layer, customer layer, integration layer, quality of service layer, information architecture \&business intellegence layerdan governance layer.

a. Operational Laye rmerupakan bagian yang menyediakan semua kebutuhan system informasi untuk menunjang proses bisnis dari perusahaan.

b. Manajemen Rumah Sakit Terintegrasi

c. Service Component Layer berisi aplikasi-aplikasi yang mengenkapsulasi aplikasi yang ada pada operational layer untuk dijadikan komponen pada servis.

d. Service Layer berisikan semua servis yang tercipta merupakan abstraksi dari proses bisnis yang ada dari pada perusahaan. Wujud dari layer ini adalah web service dan XML (extensible markup languange).

e. Consumer Layer lapisan ini menjadi perantara atau jembatan komunikasi antara business process layer dengan pengguna sistem melalui portal atau business to business (B2B).

f. Integration Layer pada layer ini tercipta suatu integrasi antara servis yang membentuk suatu Enterprise Service Bus (ESB).

g. Quality of Service Layer ini memungkin kita untuk memonitor dan mengelola servis berupa kinerja, keamanan dan ketersediaan dari servis itu sendiri.

h. Information Architecture \& Business Intellegence Layer berhubungan dengan perubahan dan pengolahan data yang mungkin bisa dimanfaatkan untuk membuat business intellegence melalui data warehouse.

i. Governance Layer, memberikan sistem pengambilan keputusan terhadap kapasitas, kinerja, keamanan dan monitoring dengan menggunakan governance layer.

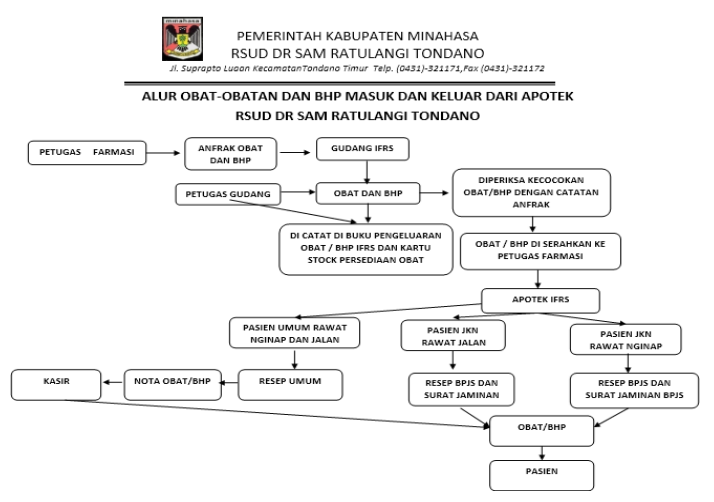

Gambar 6. Alur transaksi obat yang masuk dan keluar dari apotek

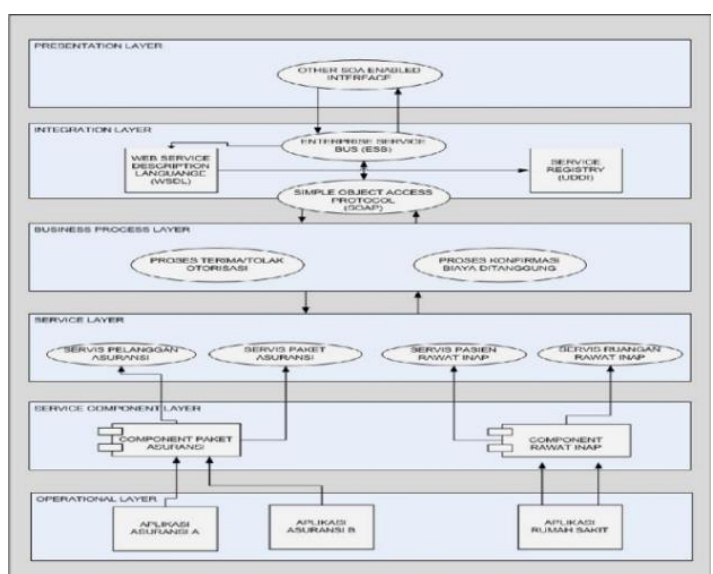

Gambar 7. Rancangan arsitektur sistem informasi 


\subsection{Keuntungan Enterprise Resource Planning (ERP)}

Pada bagian ini akan menjelaskan keuntungan apa saja jika ERP berhasil di terapkan pada sebuah rumah sakit. Disini peneliti hanya membahas keuntungan ERP pada empat departemen di rumah sakit.

a. Front Office, sering disebut juga sebagai front desk, pada bagian ini menyediakan informasi yang penting seputar data pasien.

b. Manajemen keuangan, sistem ERP dapat membantu mengidentifikasi solusi untuk mengurangi biaya, memperbaiki laporan manajerial, mengurangi risiko dan mengantisipasi hasil.

c. Manajemen persediaan, bagian ini dapat memberikan bantuan yang signifikan seperti, mengkoordinasi pembelian dan pemeliharaan instrumen, mencatat periode kadaluwarsa dan status pemesanan ulang, menemukan pemasok ekonomis.

d. Biaya Operasional sistem ERP secara signifikan mengurangi tenaga kerja yang dibutuhkan untuk mengelolapendaftaran, penagihan, pembongkaran, dan transfer data pasien. Singkatnya, sistem ERP dapat membantu rumah sakit untuk menjalankan prosesnya secara efektif (Okoli, 2010).

\subsection{Identifikasi Risiko dan Penilaian Risiko (Risk Assessment)}

Risiko dibedakan menjadi risiko potensial (pendekatan pro-aktif) dan kejadian yang telah terjadi (pendekatan reaktifresponsif). Risiko potensial diidentifikasi dari berbagai macam sumber, yaitu sebagai berikut: Informasi internal (rapat bagian / koordinasi, audit, incident report, klaim, komplain), Informasi eksternal (pedoman dari pemerintah, organisasi profesi, lembaga penelitian), Pemeriksaan atau audit eksternal.

Risiko atau insiden yang sudah teridentifikasi harus ditentukan peringkatnya (grading) dengan memperhatikan dua tingkatan yaitu sebagai berikut:Tingkat peluang atau frekwensi kejadian (likelihood) dan Tingkat dampak yang dapat atau sudah ditimbulkan (consequence).

Tabel 2. Pengukuran kualitatif frekuensi dampak (Nurzakiah, 2016)

\begin{tabular}{lll}
\hline Tingkat & Deskripsi & Nilai \\
\hline Jarang & Terjadi pada keadaan khusus & 1 \\
Kadang-Kadang & Dapat terjadi sewaktu waktu & 2 \\
Mungkin & $\begin{array}{l}\text { Mungkin terjadi sewaktu waktu } \\
\text { Mungkin Sekali }\end{array}$ & $\begin{array}{l}\text { Mungkin terjadi pada banyak } \\
\text { keadaan }\end{array}$ \\
Hampir Pasti & $\begin{array}{l}\text { Dapat terjadi pada tiap keadaan } \\
\text { dan menetap }\end{array}$ & 5 \\
\hline
\end{tabular}

Tabel 3. Pengukuran Kualitatif Konsekuensi Dampak (Nurzakiah, 2016)

\begin{tabular}{lll}
\hline Tingkat & Deskripsi & Contoh Deskripsi \\
\hline 1 & Tidak Bermakna & $\begin{array}{l}\text { Tidak ada cedera, kerugian keuangan } \\
\text { kecil }\end{array}$ \\
2 & Rendah & $\begin{array}{l}\text { Pertolongan pertama dapat diatasi, } \\
\text { kerugian keuangan sedang } \\
\text { Memerlukan pengobatan medis, } \\
\text { kerugian keuaangan besar } \\
\text { Cedera luas, kehilangan kemampuan } \\
\text { produksi, kerugian keuangan besar } \\
\text { Kematian, kerugian keuangan sangat } \\
\text { besar. }\end{array}$ \\
\hline
\end{tabular}

Tabel 4.Identifikasi Dampak (Nurzakiah, 2016)

\begin{tabular}{llllll}
\hline Peluang & $\begin{array}{l}\text { Sangat } \\
\text { Rendah }\end{array}$ & Rendah & Sedang & Besar & $\begin{array}{l}\text { Sangat } \\
\text { Besar }\end{array}$ \\
\hline Jarang- & 1 & 2 & 3 & 4 & 5 \\
Jarang & & & & & \\
Kadang & 2 & 4 & 6 & 8 & 10 \\
$\begin{array}{l}\text { Mungkin } \\
\text { Mungkin }\end{array}$ & 3 & 6 & 9 & 12 & 15 \\
$\begin{array}{l}\text { Sekali } \\
\text { Hampir }\end{array}$ & 5 & 8 & 12 & 16 & 20 \\
Pasti & & 10 & 15 & 20 & 25 \\
\hline
\end{tabular}

Keterangan:

Nilai 1-3 = Rendah

Nilai 4-6 = Sedang

Nilai 8-12 = Rendah

Nilai $15-25=$ Tinggi

Tabel 5. Resiko Potensial Berdasarkan Area (Nurzakiah, 2016)

\begin{tabular}{|c|c|}
\hline No & Area Resiko \\
\hline \multicolumn{2}{|c|}{ Akses Pasien } \\
\hline 1 & $\begin{array}{l}\text { Proses pemulangan pasien lama, Pasien pulang } \\
\text { paksa, Kegagalan merujuk pasien, Ketidaktersediaan } \\
\text { tempat tidur, dan Proses transfer pasien yang tidak } \\
\text { baik }\end{array}$ \\
\hline \multicolumn{2}{|c|}{ Kecelakaan } \\
\hline 2 & $\begin{array}{l}\text { Tersengat listrik, Terpapar dengan bahan berbahaya, } \\
\text { Tertimpa benda jatuh, Tersiram air panas dan Terpeleset }\end{array}$ \\
\hline \multicolumn{2}{|c|}{ Asesmen dan Terapi } \\
\hline 3 & $\begin{array}{l}\text { Kesalahan identifikasi pasien, Reaksi transfusi darah, } \\
\text { Kesalahan pelabelan spesimen laboratorium, Kegagalan } \\
\text { konsultasi interdisiplin pasien dan Code blue }\end{array}$ \\
\hline \multicolumn{2}{|c|}{ Masalah Administrasi Keuangan Pasien } \\
\hline 4 & $\begin{array}{l}\text { Kesalahan estimasi biaya, Pengenaan tagihan yang sama } \\
\text { dua kali, Kesalahan input data tagihan , Perbedaan tarif } \\
\text { dantagihan dan Transaksi tidak terinput }\end{array}$ \\
\hline \multicolumn{2}{|c|}{ Kejadian Infeksi } \\
\hline 5 & $\begin{array}{l}\text { Kegagalan atau kontaminasi alat medis, Infeksi luka } \\
\text { operasi, Needlestick injury, Kesalahan pembuangan limbah } \\
\text { medis dan Infeksi nosokomial }\end{array}$ \\
\hline \multicolumn{2}{|c|}{ Rekam Medik } \\
\hline 6 & $\begin{array}{l}\text { Kegagalan memperoleh informed consent, Kesalahan } \\
\text { pelabelan rekam medik, Kebocoran informasi rekam } \\
\text { medik, Ketidaklengkapan catatan dalam rekam medik dan } \\
\text { Kehilangan atau kesalahan penyimpanan rekam medic }\end{array}$ \\
\hline \multicolumn{2}{|c|}{ Obat } \\
\hline 7 & $\begin{array}{l}\text { Penulisan resep yang tidak baik, Riwayat alergi obat tidak } \\
\text { teridentifikasi, Kesalahan dosis obat, Obat rusak atau } \\
\text { expired, Kesalahan identifikasi pasien dalam pemberian } \\
\text { obat dan Kegagalan memonitor efek samping obat }\end{array}$ \\
\hline \multicolumn{2}{|c|}{ Keamanan } \\
\hline 8 & Pencurian, Pasien hilang dan Lingkungan yang tidak aman \\
\hline
\end{tabular}




\subsection{Analisa Resiko}

Analisa dilakukan dengan menentukan score atau nilai terhadap risiko yang ada. Manajemen harus bertanggung jawab dalammengelola dan mengendalikan risiko. Kejadian tersebut termasuk dalam kategori hijau, kuning, ungu dan merah.

Tabel 6. Analisa Resiko (Nurzakiah, 2016)

\begin{tabular}{ll}
\hline Tingkat Resiko & Peluang atau Frekuensi \\
\hline 1 & Sangat jarang(>5 tahun/kali) \\
2 & Jarang $(>2-5$ tahun/kali) \\
3 & Mungkin $(1-2$ tahun/kali) \\
4 & Sering(beberapa kali/tahun) \\
5 & Sangat sering(tiap minggu/ bulan) \\
\hline
\end{tabular}

Risiko atau insiden yang sudah dianalisis akan dievaluasi lebih lanjut sesuai skor dan grading yang didapat dalam analisis.

\section{SKOR RISIKO = DAMPAK X PELUANG}

Pemeringkatan memerlukan keterampilan dan pengetahuan yang sesuai, dan meliputi proses, yaitu :

a. Menilai secara obyektif beratnya, dampak, akibat dan menentukan suatu score.

b. Menilai secara obyektif kemungkinan, peluang, frekuensi suatu peristiwa terjadi dan menentukan suatu skor.

c. Mengalikan dua parameter untuk memberi score resiko 3 .

Penilaian risiko akan dilaksanakan dalam dua tahap, yaitu sebagai berikut:

a. Tahap pertama akan diselesaikan oleh penilai risiko yang terlatih, yang akan mengidentifikasi bahaya, efek yang mungkin terjadi dan pemeringkatan risiko.

b. Tahap kedua dari penilaian akan dilakukan oleh Kepala Unit Kerja yang akan melakukan verifikasi tahap pertama dan membuat suatu rencana tindakan untuk mengatasi risiko pada RSUD Dr. Samratulangi Tondano.

\subsection{Kelola Resiko}

Setelah tahapan identifikasi, analisis dan evaluasi selesai maka tahapan selanjutnya adalah mengelola risiko atau kejadia dengan menghilangkan atau menekan risiko sehingga menuju kepada level terendah dan meminimalkan dampak dan kerugian yang ditimbulkan dari kejadian insiden yang telah terjadi.

\section{Kesimpulan}

Berdasarkan pembahasan dijelaskan diatas maka kesimpulan yang didapatkan masalah bahwa sering munculnya masalah ketidaksesuaian data atau informasi disetiap divisi di rumah sakit sehingga bisa menjadi hambatan terhadap kinerja rumah sakit dalam memberikan pelayanan prima kepada para pasien. Penerapan sistem ERP dan managemen risiko dapat membantu perusahaan dalam mencapai tujuan bisnis dan meningkatkan kualitas pelayanan kesehatan. Penerapan sistem ERP dan managemen risiko di bidang kesehatan dapat membawa sebuah perubahan yang cepat, memimpin organisasi yang relevan dan dapat merespons kebutuhan pasar saat ini. Namun di dalam penerapan sistem ERP pihak RS akan menghadapi masalah manajemen yang serius, yang terutama disebabkan oleh banyaknya informasi yang dihasilkan setiap hari, meningkatnya biaya persediaan, kegagalan sensus pasien, pembayaran medis, kurangnya staf khusus dan lain sebagianya.

Pendekatan teknologi yang bisa dilakukan untuk pengintegrasisan sistem informasi adalah dengan memanfaatkan ERP dan managemen resiko, dimana akan dicapai keseragaman data khususnya pasien yang akan membantu proses pelayanan rumah sakit yang lebih baik. Dengan adanya penerapan sistem ERP dan managemen risiko maka sebuah RS dapat meningkatkan kualitas pelayanan, mendapatkan informasi pasien secara real time, perencanaan menjadi terorganisir, memudahkan proses monitoring, dan mempermudah proses pengambilan keputusan dan kebijakan dalam manajemen rumah sakit.

Disarankan untuk kedepannya penelitian ini dapat di terapkan dan dikembangkan pada RSUD Dr. Samratulangi tondano agar dapat mengurangi manajemen resiko pada rumah sakit tersebut.

\section{Ucapan Terima Kasih}

Terima kasih banyak kepada manajemen dan pimpinan kampus Universitas Atma Jaya Yogyakarta khususnya Bapak Djoko Budiyanto Setyohadi yang telah membantu dalam penelitian ini.

\section{Daftar Pustaka}

Agarwal, D., Garg, P., 2012. ERP implementation in hospitals: a case study. International Journal of Electronic Healthcare, 7(2), 157

Alexandra, I., 2012. Etika dan Hukum dalam Pelayanan Kesehatan. Jakarta: Graha Ilmu

Al-Zaidiyeen, N.J., Mei, L.L., Fook, F.S., 2010. Teachers' Attitudes and Levels of Technology Use in Classrooms: The Case of Jordan Schools. International Education Studies 3(2).

Azhari, R., 2015. Implementasi Enterprise Resource Planning (ERP) Pengadaan Bahan Baku dan Pengelolaan Produksi Pada Perusahaan Furniture Menggunakan ADempiere (Studi Kasus: CV Roland Kencana). 1 September 2016.

Chen, E.T., 2016. Examining the Influence of Information Technology on Modern Health Care. In: Effective Methods for Modern Healthcare Service Quality and Evaluation. IGI Global, 110-136.

Debiao, H., Jianhua, C., Rui, Z., 2011. A more secure authentication scheme for telecare medicine 
information systems. Journal of Medical Systems 36(3), 1989-1995.

Depkes, RI., 2009. UU No. 44 Tahun 2009 Tentang Rumah Sakit. Jakarta: Depkes RI.

Depkes, RI., 2011. Peraturan Menteri Kesehatan Republik Indonesia Nomor 1171/MENKES/PER/III/2011 Tentang Sistem Informasi Rumah Sakit. Jakarta: Depkes RI.

Edy, I., 2014. Pengantar Teknologi Informasi. Yogyakarta: Deepublish

El-Kareh, R., Hasan, O., Schiff, G.D., 2013. Use of health information technology to reduce diagnostic errors. BMJ Quality \& Safety, 22(Suppl 2), 40-51.

Garg, P. and Agarwal, D., 2014. Critical success factors for ERP implementation in a Fortis hospital: an empirical investigation. Journal of Enterprise Information Management 27(4), 402423.

Gheorghiu, B., Hagens, S., 2016. Measuring interoperable EHR adoption and maturity: a Canadian example. BMC Medical Informatics and Decision Making 16(1).

Handayani, P.W., Rahman, M.Z., and Hidayanto, A.N., 2013. Information technology assessment on hospital information system implementation: case study ateaching hospital. International Journal of Engineering and Technology.

Hemsley, B., Balandin, S., Worrall, L., 2011. Nursing the patient with complex communication needs: time as a barrier and a facilitator to successful communication in hospital. Journal of Advanced Nursing 68(1), pp.116-126. Hriningsih, S.P. Information Technology. Yogyakarta: Graha Ilmu, 2005

Huq, N., Shah, S.M.A., Mihailescu, D., 2016. Why Select an Open Source ERP over Proprietary ERP? In: Small and Medium Enterprises. [online] IGI Global, 1654-1676.

Iskandar, H, Maksum, H., Maksiah, 2014. Faktor penyebab penurunan pelaoporan insiden keselamatan pasien rumah sakit, Program Studi Magister Manajemen Rumah sakit, Universitas Brawijaya, Malang.

Karan, O., Bayraktar, C., Gümüşkaya, H., Karlık, B., 2012. Diagnosing diabetes using neural networks on small mobile devices. Expert Systems with Applications 39(1), 54-60.

Keputusan Menteri Kesehatan Republik Indonesia, Nomor: 377/Menkes/SK/III/2007, 2017. Tentang Standar Profesi Perekam Medis dan Informasi Kesehatan, Jakarta 2007.
Kerezoglou A., 2011. Internal Audit and Accounting Standard Setting in healthcare organizations.

Lee, C.W., Kwak, N.K., 2009. Strategic enterprise resource planning in a health-care system using a multicriteria decision-making model. Journal of Medical Systems 35(2), 265-275.

Maditinos, D., Chatzoudes, D., Tsairidis, C., 2011. Factors affecting ERP system implementation effectiveness. Journal of Enterprise Information Management 25(1), 60-78.

Mawarni, D., Ratna D.W., 2013. Identifikasi ketidaklengkapan rekam medis pasien rawat inap rumah sakit Muhammadiyah Lamongan. Jurnal Administrasi Kesehatan Indonesia, Vol. 1 nomor 2 April- Juni 2013.

Nowak, G., 2014. Description of the MHS Health Level 7Radiology for Public Health Surveillance (No. NMCPHC-EDC-TD-5-2014). Navy and MarineCorps. Public Health Center, Portsmouth.

Purnawati, Setyohadi, 2017. The Analysis of implementation business model canvas at the emarketplace dipeta company. Scientific Journal of Informatics 4 (2), 125-133.

Okoli, C., Schabram, K., 2010. A guide to conducting a systematic literature review of information systems research. SSRN Electronic Journal.

Oluwatosin, H.S., 2014. Client-Server Model. IOSR Journal of Computer Engineering, [online] 16(1), 57-71.

Padhy, R.P., Patra, M.R., Satapathy, S.C. 2012. Design and implementation of a cloud based ruralhealthcare information system model. Universal Journal of Applied Computer Science and Technology,2(1), 149-157.

Poba-Nzaou, P., Uwizeyemungu, S., Raymond, L., Paré, G., 2012. Motivations underlying the adoption of ERP systems in healthcare organizations: Insights from online stories. Information Systems Frontiers 16(4), 591-605.

Republik Indonesia, 2014. UUD Nomor 46 Pasal 1 Tahun 2014, tentang Sistem Informasi Kesehatan. www.kemenkopmk.go.id

Sutarman, 2009. Pengantar Teknologi Informasi. Jakarta: Bumi Aksara.

Snyder, R., Hamdan, B., 2010. ERP and Success Factors. ASBBS Annual ConferenceProceedings, Las Vegas, Vol. 17, No.1

Zhu, Z., 2012. An efficient authentication scheme for telecare medicine information systems. Journal of Medical Systems, 36(6), 3833-3838. 